\title{
Indisciplining the Curriculum From a Complex Perspective to Teach English
}

\author{
Martha Moreno ${ }^{1,2}$ \& Milton Pájaro ${ }^{1,3}$ \\ ${ }^{1}$ Universidad de Córdoba, Montería, Córdoba, Colombia \\ ${ }^{2}$ Institución Educativa Cecilia de Lleras, Montería, Córdoba, Colombia \\ ${ }^{3}$ Institución Educativa Antonia Santos, Montería, Córdoba, Colombia \\ Correspondence: Milton Pájaro, Transversal 12 • 1-11 Barrio Galilea, Montería, Córdoba, Colombia. Tel: \\ 301-735-7916. E-mail: miltonpama@gmail.com
}

Received: July 7, 2018 Accepted: August 7, 2018 Online Published: August 8, 2018

doi: 10.5539/elt.v11n9p26 URL: http://doi.org/10.5539/elt.v11n9p26

\begin{abstract}
This article presents a constructive criticism and also a prospectus about the suggested curriculum and the process of indisciplining the curriculum. It considers that through a process of indisciplining the English curriculum it would be possible to achieve the goals stated by the National Ministry of Education in terms of bilingualism and education quality. The article starts with a presentation of the educational reality of the country, the advances and transformation obtained in terms of bilingualism during the last years. Afterwards, it presents synthesis of the positive aspects of the suggested curriculum presented by the National Ministry of Education for the teaching of English as a foreign language in all the public schools of Colombia. Finally, the concept of indisciplining the curriculum in the English subject is presented as a proposal that would achieve meaningful progress in terms of English teaching and the education of students with critical thinking, complex and transformer of his/her society.
\end{abstract}

Keywords: transcomplexity, suggested curriculum, complexity, indisciplining, foreign language

\section{Introduction}

Nowadays it is common to read, listen and talk about the evolution, transformation and the crisis that education is living in this era. However, schools are the ones which are in crisis as a result of that transformation and evolution process (Calvo, 2013).

This article emerges from this idea and states a difference between education quality and school quality in order to ask the following question: Why is it important to establish a difference between these two concepts?

The answer is relevant if we think about the real concept of quality in terms of education, so that clear contributions can be made to the curriculum, public education politics, teaching, financing, among other aspects.

There is something certain about this, all the ones who are living what is going on nowadays are experiencing changes, uncertainties, problems, globalization, technological evolution and complexity in all aspects (Arellano, 1996). This reality makes people to stake out different concepts such as: the real philosophy of education quality, the goals stated with the curricular proposals that have been published throughout the country and some educational paradigms that have been that are being handled by the different subjects within the educational system.

The real sense of education quality is only possible if the curriculum is undisciplined. This could take place through if it is imbalanced, disorganizing what is already organized (Calvo, 2013). Maintaining an equilibrium and starting an organized and predictable repetition of educational practices implies a risk which is the routinization of education making it difficult the goal of achieving its real quality. For this reason, it is necessary to indiscipline the pedagogical practices, the thoughts of learners and teachers, the content, in other words, it is necessary to indiscipline the curriculum.

Then, to indiscipline the curriculum corresponds to the problematization of the society, questioning it and its reality, questioning what is considered real and what it is not, to indiscipline the curriculum is to enter a religation process $<<$ disorganized what is already organized $>>$, avoiding the reductionism, fulfillment of 
standards and the linearization of education.

\section{Suggested Curriculum to Teach English as a Foreign Language}

Part of the dynamics of the transformation, liberation and evolution of a society is centered on education, on the integral formation of the human being. González (2009: 15) considers that: "Education should be the tool that liberates human beings from their reductionism and leads to the complexity of their actions" From his point of view about complexity, González places education as the most important pillar to achieve real social transformation. Society, the educational community and the government constantly make efforts to improve educational practices; however, these efforts do not always yield the expected results. Colombia is not far from this reality and this is evidenced in the strategic lines of the current government, which includes education as one of the three elements that guide the national development plan 2014-2018, (Congress of the Republic of Colombia, 2015), along with two other main lines of the government plan that are peace and equity. The national development plan seeks to make significant contributions to achieve the goal of making Colombia the most educated country in the region by the year 2025 .

The current government has sought to strengthen education by addressing key aspects that lead to "quality" such as: educational coverage, Expanding the number of hours devoted to teach, the improvement of infrastructure, national plans for training teachers, the creation and publication of ministerial directives that guide the educational practices (Curriculum for primary, Basic Learning Rights for the main subjects, suggested curriculum, among other documents). In this section we talk about "quality" because it is a concept that can be approached and understood from different perspectives. For example, according to Correa (2013) from the technical rationality of those responsible for guiding the educational horizon at the state level, (who in this regard have a technical and economic perspective), quality is analyzed and made visible through indicators of effectiveness and efficiency. Education is effective if the objectives and goals stated in a curricular project, which responds mostly to particular interests and not the interests of all members of society, are achieved. On the other hand, education is efficient when there is an optimal use of the resources that are available, which means that quality is measured from a purely economistic point of view.

Correa (2013: 192) defines educational quality as the one that "advocates the full transformation of the student so that it can responsibly influence social development". In this sense, the true meaning of what is educational quality should focus on the promotion and development of teaching practices where individuals learn to learn, are holistically trained and can thus intervene responsibly in the society where they live.

Regarding education, the teaching of English as a foreign language has become one of the main and most promoted programs of the national education ministry. Proof of this has been the strengthening and prominence of the national bilingualism plan (Ministry of National Education of the Republic of Colombia, [MEN], 2014a) throughout the country. Before continue talking about this, it is necessary to have clear what is meant by bilingualism? According to Bloomfield (1984) in his book Language, bilingualism can be understood as a native-like control of two languages. Haugen (1953) complement this point of view staying that bilingualism begins at the point of view where the speaker of one language is able to produce meaningful utterances in more than one language.

Coming back to the topic of the national bilingual plan in Colombia, these public policies have included strategies for the continuous improvement of the disciplinary training of teachers, improvement of the teaching processes that are daily applied in the classrooms, improvement of the teaching materials used by the students; national and international immersions for teachers, inter-institutional accompaniment, training workshops, promulgation and training in the application of curricular guidelines at the national level, provision of texts and teaching materials relevant to the regional and national context, among others. These strategies have been carried out by the government to achieve the goals it has stated regarding bilingualism (MEN, 2006).

Currently, in Colombia, there are other additional documents that seek to improve the pedagogical practices that are developed in English; These documents are: Guidelines for the implementation of projects to strengthen English in territorial entities (MEN, 2014b), the basic learning rights to teach English in primary, the basic learning rights to teach English in high school (MEN, 2016b) and the suggested curriculum (MEN, 2016c). These documents are based on an international reference called the Common European Framework of Reference, (Council of Europe [CE], 2001) which describes what students of any language must certify to be classified at a certain level of language management. The documents designed by the ministry are a way to plan, organize and develop the educational practices that teachers implement within their classrooms. Through these tools students are expected to reach an English level that allows them to communicate, interact and share knowledge in a foreign language. 
There are different opinions regarding the importance, relevance and impact that the instruments mentioned above can have in order to get an improvement in the educational "quality". The current analysis seeks to take up all these opinions in a reflexive-constructive way in order to analyze the current reality and be able to link that with the unsdisciplined curriculum in a contextualized way. In order to achieve this, an analysis will be made on the last document published by the national education ministry: the suggested curriculum. On the one hand, the positive aspects of this document will be shown and then the concept of undisciplined curriculum will be discussed as an option that would allow to give a new meaning to the concept of educational quality.

Before tackling this dichotomy, we will look a little bit at the context surrounding the suggested curriculum that is now used as a reference in public educational institutions in the country, for the teaching of English as a foreign language

The construction of the suggested curriculum has its genesis in an in-depth study of the characteristics and needs of the national educational sector. This study was conducted by national and international experts who, under the guidance of the national education ministry, made an initial proposal of a suggested curriculum that was evaluated and given feedback by 94 English teachers belonging to different universities and different certified education secretariats in the country. Finally, from this exercise different axes that guide the teaching of English emerged. In theory, those axes can be adapted to all the school contexts of our country.

The main purpose of the publication of this document by the national education ministry is to provide new tools for teachers and educational institutions to build a bilingual Colombia and thus achieve the goal of being the most educated country in the region by the year 2025 .

\subsection{Pros of the Suggested Curriculum}

As it was stated above it will be assumed a position in which besides making a reflexive-constructive criticism about the curricular orientation that the teaching of English in Colombia should take, it will be highlighted the successes of the suggested curriculum proposal to teach English that currently exists. These pros can be summarized in seven different aspects:

\subsubsection{Needs Analysis}

The fact of having started with a needs analysis and a study of the historical reality of teaching and learning English as a foreign language and contrasting this historical reality with the progress that has been made in the field of bilingualism in the last two decades was an excellent starting point to make a proposal intended to adapt itself to the needs of the actors of the national educational system in regard to the teaching and learning of this foreign language.

\subsubsection{Adjustment to National and International References}

Another positive point of the suggested curriculum was the idea to take into account different national references such as the model of unification of criteria through a continuous curriculum construction proposed by the education secretary of Neiva (Ministry of Education) or the curriculum proposed by the Secretary of Education of Medellín (2014) in which 13 books were proposed for the organization of contents of the compulsory areas for all grades and levels.

At the international level, the design of the suggested curriculum is based on the successful experience of countries such as Mexico and Costa Rica. These countries have worked hard in their bilingual education policies to achieve the goal of having students in intermediate level of English once they finish high school. The other international benchmark and perhaps the most important of all has been the Common European Framework of Reference (CEFR) which defines the different levels of language that a learner of a foreign language must have in the different skills of a language (reading, writing, speaking and listening).

\subsubsection{Pedagogical Practices Transformation}

Although implicitly this curricular proposal for the teaching of English as a foreign language responds to a policy of educational quality viewed from the effectiveness and efficiency point of view, it deserves recognition the concern to achieve a transformation of pedagogical practices. Years ago the teaching of English was influenced by methods and approaches such as the grammatical and translation method, the naturalistic approach or the total physical response method (Richards \& Rodgers, 2001) which were characterized by being slow, decontextualized and non-effective.

\subsubsection{Variety of Instruments and Tools}

Different from the curricular proposals people were used to, in which everything was reduced to a simple content guide to be developed, the suggested curriculum provides pedagogical, curricular, methodological and evaluation 
principles, which gives a quite complete course about the horizon that must have English education in the different schools of the country.

2.1.5 Curricular Framework to Establish Relationships Among the Macro-curriculum, the Meso Curriculum and the Micro Curriculum

The suggested curriculum for the teaching of English as a foreign language, organizes its proposal into a curricular framework in which the macro, meso and micro relationships can be easily noted. According to Posner (2005) this curricular framework includes aspects such as: the scope and sequence, programs of study, content scheme, standards, textbooks, study routes and planned experiences. These elements of the macro-curriculum, the meso-curriculum and the micro-curriculum interact among themselves giving a logical sense to the curricular proposal.

\subsubsection{Organizing Contents into Four Curricular Axis}

This curricular proposal has considered transversality as a key point in its development. The contents have been organized into four curricular axes: Environmental education and sustainability, Education for sexuality / health, Construction of citizenship, and Globalization. These axes were not chosen at random; they are based on what is stated in article 14 of Law 115 of 1994, which talks about the elements that are part of compulsory education in the official and private schools of the country.

\subsubsection{Development of 21st Century Skills}

Finally, this curricular proposal aims to develop 21 st century skills on learners. Skills such as: learning and innovation, critical thinking, problem solving, digital literacy, skills for work and life, and leadership and personal responsibilities, proposed by Trilling and Fadel (2009) can be noticed in the suggested curriculum proposed by the national ministry of education.

\section{Indisciplining the Curriculum}

Before going through the issue of indisciplining the curriculum it is necessary to have clarity about certain concepts that are closely related to this topic. Firstly, it is necessary to clarify what is meant by complexity. According to Torres (2017: 1) who bases his definition on what was exposed by Morín, E (2004). "Complexity is, effectively, the fabric of events, actions, interactions, feedback, determinations, hazards, which constitute our phenomenal world. So complexity is presented with the disturbing features of the entangled, the inextricable, the disorder, the ambiguity, the uncertainty". We live in a world which is complex by nature, this world constantly changes and requires a permanent transformation. Having clear and keeping this principle in mind is fundamental for making a curricular proposal that responds to the needs of society.

The second concept that must be clarified is transcomplexity. According to González (2013) this concept arises from a symbiosis between what is understood by complexity and the concept of transdisciplinarity at an educational level. For González (2013) transcomplexity refers to everything that is between, through and beyond the disciplines themselves. In other words, the subject that is intended to be formed from this new concept is one that always seeks to cross the frontier of teaching and learning, a subject that seeks social and individual transformation, an individual that pretends to disrupt what is already ordered to give a new order and give a new meaning to what is already known.

The third and last concept that needs to be clarified is indiscipline. According to the dictionary of the real academy of the Spanish language (s.f.), the prefix in, indicates denial or deprivation. In this sense, the term indiscipline indiscipline refers to the process that is contrary to the discipline or instruction imposed on something, on a person or a group of people.

Through an undisciplined curriculum for the teaching of the English, it is aimed to take the foundations of the complex thought of Morín, and transcomplexity, to achieve a disorganization of everything that the world proposes and shows us as completed and organized so that this can be given new meanings and can be reorganized and achieve in that way a transformation and a better understanding of the society where we live in. Calvo (2013) believes that this is the only way human beings can create and generate knowledge.

Calvo (2013: 59) states that: "There is creation when chaos messes up the pre-existing relative order, eliminates the original meaning and creates a new one, based on the new relationships. Both, chaos and order, have to do with the creative process".

Taking into account what was stated above, the suggested curriculum to teach English should consider a new challenge: The indiscipline of the curriculum based on the socio-construction of each school, from each particular context, since the needs, characteristics and objectives of each community education can be similar, 
but not exactly the same. The indiscipline becomes a key aspect in this process of socio-construction of the curriculum so that new paradigms are generated in relation to the integral education of the learner and new forms of active participation of the citizen in their community. Although the suggested curriculum has interesting aspects as it was mentioned before, the fact that it is a national proposal to some extent adaptable, makes it necessary to think and reflect on it as it will continue to provide an education that only seeks to train citizens who are used to respond to indicators of effectiveness, efficiency, and competitiveness looking at education from an economic point of view.

The patterns that have been lately followed, suggested from the subjectivity of a small group of people in an office, which, seem adaptable to any context, do not seem to be assertive; The application of guidelines in a procedural way is not what the current society requires to achieve its transformation and the empowerment of its members to make visible constant and meaningful changes that lead them to live better. In Words of Cadavid and Calderon, (2004), it is a matter of following a bit the principles of the Humanities Curriculum Project led by Stenhouse, Elliot and other collaborators between 1967 and 1972, where it was concluded that social researchers were not the ones who had to make decisions about the educational system. Instead, the teacher must become a manager, transformer and executor of the curriculum by relying on researchers outside the school and not depending on what they have (Cadavid and Calderón, 2004). It is necessary to give a new meaning to the educational act through teacher researchers (Ossa, 2015). If each educational institution assumes the task of indisciplining its own curriculum on a permanent basis, taking into consideration what is available and what is needed, selecting its own pedagogical models, its own materials, strategies, and other aspects that are part of the curriculum, then it will be possible to stop training a citizen that responds to the needs and interests of a small group of people, giving many steps towards achieving the goal of being the most educated country in the region by 2025 .

\section{Conclusions}

To be the most educated country in South America by 2025 is difficult but not impossible. One evidence that it is not something easy is the result of the evaluation made to the two last ten year plans of education which have shown that certain changes and progress have been achieved regarding education but there are many things that need to be achieved if the goals and indicators established by the UNESCO and the UN in regards to education for Latin America.

Different actions and plans have been carried out regarding education in Colombia. They include the publication of basic learning rights for English and other subjects and also the publication of the suggested curriculum to teach English which have been very important and have allowed to break old paradigms about how to teach and how to learn. However, it is necessary to recognize that even though the suggested curriculum is a flexible and adaptable proposal, the reality of each context as well as the particular characteristics of each school in Colombia demand a wider though about education using the principles of the complex though, transcomplexity, indisciplining the curriculum in order to propose new educational paradigms to teach foreign or second languages.

If education continues its progress under patterns that have been established and have their genesis in a centralized way, the pedagogical practice will continue being developed far from the particular context of each school, far from the elaboration of complex explanations, and far from the formation of critical citizens, agents of change and transformation of the community where they live.

Indisciplining the English curriculum could be the road to follow to get closer to the goals that our country has established regarding bilingualism in the different education levels according to the Common European Framework of Reference to learn a foreign language.

\section{References}

Alcaldía de Medellín. (2014) Expedición Currículo. Retrieved from http://medellin.edu.co/escuelaentornoprotector/documentos-eep/274-1-plan-estudios-educacion-formal/file

Arellano, A. (1996). El Pensamiento Pedagógico, en Educar, Enseñar y Aprender. Consejo de Publicaciones. Mérida.

Bloomfield, L. (1984). Language. Chicago. University of Chicago Press.

Cadavid, A., \& Calderón, I. (2004) Análisis del Concepto Enseñanza en las Teorías Curriculares de Lawrence $\begin{array}{lllll}\text { Stenhouse } & \text { y } & \text { José } & \text { Jimeno } & \text { Sacristán. }\end{array}$ http://aprendeenlinea.udea.edu.co/revistas/index.php/revistaeyp/article/view/6019 
Calvo, M. C. (2013). Del Mapa Escolar al Territorio Educativo: Disoñando la escuela desde la educación. Editorial Universidad de la Serena. La Serena, Chile.

Congreso de la República. (2015). Ley 1753: Plan Nacional de Desarrollo 2014 - 2018 “Todos por un nuevo país".

Consejo de Europa: Departamento de Política Lingüística. (2001). Marco común europeo de referencia para las lenguas: aprendizaje, enseñanza, evaluación. Retrieved from http://cvc.cervantes.es/obref/marco/

Council of Europe (2002) Marco Común Europeo de Referencia. Retrieved from https://cvc.cervantes.es/ensenanza/biblioteca_ele/marco/cvc_mer.pdf

Congreso de la República de Colombia. (1994). Ley General de educación. Santa Fe de Bogotá, Available in: http://www.mineducacion.gov.co/1621/articles-85906_archivo_pdf.pdf

Correa de Molina, Cecilia. (2013). Currículo Transdisciplinar y Práctica Pedagógica Compleja. Instituto de Investigaciones. Grupo de investigación Religación Educativa Compleja-RELEDUC. Colección Educación, complejidad y transdisciplinariedad. Ediciones Universidad Simón Bolívar. Barranquilla, Colombia

Diccionario de la real academia española. (N.D.) Significado del prefijo in. Available in: http://dle.rae.es/?id=DsHNOud|DsHt84Y

González, V. J. (2009). Teoría Educativa Transcompleja. Instituto internacional de integración convenio Andrés Bello. Colección Educación Compleja Transdisciplinar. La Paz, Bolivia.

González, V. J. (2013). Currículo Transcomplejo: Pensamiento Transcomplejo. Tomo IV. Colección Educación, Complejidad y Transdisciplinariedad. Ediciones Universidad Simón Bolívar, Barranquilla, Colombia.

Haugen, E. (1953). The Norwegian language in America: A study in bilingual behavior. Vol. 1: The bilingual community; Vol. II. The American dialects of Norwegian. Bloomington: Indiana University Press. https://doi.org/10.9783/9781512820522

Ministerio de Educación Nacional. (2006). Guía ํㅜ 22 Estándares Básicos de Competencias en Lenguas Extranjeras: Inglés, Bogotá, Colombia

Ministerio de Educación Nacional. (2014a). Programa Nacional de Inglés 2015-2025. Bogotá D.C.

Ministerio de Educación Nacional. (2014b). Orientaciones para la implementación de proyectos de fortalecimiento de inglés en las entidades territoriales. Bogotá, Colombia

Ministerio de Educación Nacional. (2016a) Derechos Básicos de Aprendizaje: inglés- Grados 6-11. Bogotá, Colombia.

Ministerio de Educación Nacional. (2016b) Derechos Básicos de Aprendizaje: inglés- Grados Transición a $5^{\circ}$ de Primaria. Bogotá, Colombia.

Ministerio de Educación Nacional. (2016c). Orientaciones y Principios Pedagógicos: Currículo Sugerido de inglés. Bogotá, Colombia.

Morín, E. (2004). Introducción al pensamiento complejo. México, D. F.: Editorial Gedisa.

Ossa Montoya, A. F. (2015). Lo pedagógico y el maestro investigador. Revista Virtual Universidad Católica del Norte, $44, \quad 102-118 . \quad$ Retrieved $\quad$ from http://revistavirtual.ucn.edu.co/index.php/RevistaUCN/article/view/618/1153

Posner, G. J. (2005). Análisis de currículo (3rd. ed.). Santa Fe de Bogotá, Colombia: McGraw-Hill S.A.

Richards, J y Rodgers, T (2001) Approaches and Methods in Language Teaching. Cambridge, Cambridge University press. https://doi.org/10.1017/CBO9780511667305

Secretaría de Educación Municipal de Neiva. (2009). Currículo Unificado de Inglés. Retrieved from https://sites.google.com/site/curriculounificadoinglesneiva/home

Torres, A. (2017). Complejidad de los sistemas educativos. Apuntes Pedagógicos. Retrieved from http://www.milenio.com/firmas/alfonso_torres_hernandez/complejidad-sistemas-educativos-milenio_18_99 6080438.html.

Trilling, B., \& Fadel, C. (2009). 21st century skills: Learning for life in our times. San Francisco, CA: Jossey-Bass. 


\section{Copyrights}

Copyright for this article is retained by the author(s), with first publication rights granted to the journal.

This is an open-access article distributed under the terms and conditions of the Creative Commons Attribution license (http://creativecommons.org/licenses/by/4.0/). 